\title{
Managing Human Waste in Informal Settlements: Bio-centres in Kibera Informal Settlement, Kenya
}

\author{
Munala Gerryshom Kweya ${ }^{1, *}$, Mugwima B.N. ${ }^{1}$, Omotto J. ${ }^{2}$, Rosana, E. ${ }^{1}$ \\ ${ }^{1}$ Centre for Urban Studies, Jomo Kenyatta University of Agriculture and Technology, Kenya \\ ${ }^{2}$ Umande Trust, Kenya
}

Copyright $\mathrm{O} 2016$ by authors, all rights reserved. Authors agree that this article remains permanently open access under the terms of the Creative Commons Attribution License 4.0 International License

\begin{abstract}
Human waste can become an eye-sore when not properly disposed off. It is estimated that every human generates about $300 \mathrm{~g}$ of human waste per day. In Kenya's largest informal settlement, Kibera - with a population of over one million people - the phenomenon of the "fly toilet" is a daily scourge to life here. Umande and its partners have built 57 bio-centres in Nairobi. Bio-centres have turned the mountains of odorous human waste from a problem into an asset. The purpose of this paper is to demonstrate how innovative solutions can be made to tackle sanitation challenges and turn envisaged waste into a resource. A survey of the constructed bio-centres in Kibera was made to assess the versatility of the bio-centres. It was revealed that the bio-centres in Kibera have collected $60,000 \mathrm{~kg}$ of human waste and turned it into biogas. They have further improved access to proper sanitation to the community and built the capacity of community-based organizations to design, plan, construct, manage, and market ecological sanitation services. These bio-centres have reduced methane emissions to the environment are definitively scalable renewable energy source option in the informal settlements.
\end{abstract}

Keywords Bio-centre, Human Waste, Informal Settlement, Kibera

\section{Introduction}

Despite bold efforts by a range of actors to improve sanitation, a significant majority of households in urban areas in developing countries especially in Africa have yet to gain access to decent, dignified, healthy and affordable sanitation choices. Slums the world over are hidden from the public view, located far from highways, on slopes, dumps, wetlands and in the shadow of the sun. Slum dwellers make up 55 per cent of the urban population in Kenya, which amounts to six million.

The Bio-Centre Initiative fronted by Umande Trust in Kibera informal settlement in Nairobi has purposed to create and improve bio-centres as locations for sanitation but also livelihood improvements within a densely populated community. The initiative has created $57+$ bio-centres serve as multi-purpose service points, designed to improve access to decent and affordable sanitation, convert human waste into clean energy (biogas) and fertilizer for urban greening, and provide income generation and access to information to community-based enterprises.

The project's objective is to explore innovations in Bio-Centre pricing, payment systems, and money management tools to improve access to healthier sanitation while at the same time improving household livelihoods through creation of income generation opportunities.

Through its vision of a healthy, environmentally-friendly "reinvented toilet," priced for universal usage yet scalable without need for subsidy; and which is leveraged to incentivize the phasing out of unhealthy surrounding pit latrines. Umande trust has successfully re-socialised the people of Kibera to view human waste as a resource that can benefit them. The project is committed to affordability and specifically aims to contribute to healthy urban sanitation at a user cost of around $\$ 0.05$ per household per day [1]. Primarily, the initiative focuses on the inter-twined and reinforcing the 4Ps: pricing, [healthy] practices, payment systems, and profitability.

The initiative has actively engage community groups, small-scale service providers, civil society, and the public, financial, and private sector in an on-going process of dialogue, learning and strategy development. Through selected cases, this paper demonstrates how community empowerment can be leveraged to improve sanitation within an otherwise underprivileged locale.

\section{The Need to Improved Access to Sanitation}

Kibera informal settlement has the unfavorable title of being the community of the "flying toilets"- the bags of human waste that are thrown out of the windows of the 
thousands of small shacks that make up Nairobi's slums. But Umande Trust has taken upon itself to rid off the informal settlements of this title through provision of solutions. According to Omotto [2], if open defecation was banned in Nairobi today, every member of the informal settlements would have to queue for two days to use the existing toilet facilities. The odorous human waste has been turned from waste into assets through bio-centres. Bio-centres in the context of Kibera are generally - toilet facilities where human slurry is collected and put in a digester which collects the methane emitted from human waste as it breaks down. The methane is sold back to the slum dwellers as biogas, used for cooking within the centres or to power hot showers. Omotto further points out that every individual creates $300 \mathrm{~g}$ of human waste each day, and $60 \%$ of Nairobi's four million inhabitants live in its informal settlements - that's 2.4 million people. If this can be harnessed then Nairobi has $720,000 \mathrm{~kg}$ of human waste which can be converted to biogas. However, if left unattended, this waste is likely to be released into the atmosphere as methane, a greenhouse gas, which would exacerbate global warming.

\section{Anaerobic Digester Basics}

Biogas digesters work on the principal of anaerobic digestion - a natural, biological process similar to composting that breaks down liquid manure, sewage, or other organic wastes. In the process, biogas is produced. This biogas is about $55-70 \%$ methane (the primary component of natural gas) and therefore can make an excellent energy source [3].

According to the manual, anaerobic means "without oxygen," and the bacteria that produce the biogas can only survive if they are not exposed to oxygen in the air. These bacteria generally thrive at two temperature "zones" from $95-105 \mathrm{oF}$, and from 125 to $135 \mathrm{oF}$. Although anaerobic digestion occurs at lower temperatures, it is not as efficient at producing biogas.

\section{Environmental Benefits}

Anaerobic digestion offers several environmental benefits. Among these benefits are [4]:

(i) Odor Reduction

Odors are significantly reduced in an anaerobic digestion system.

(ii) Green Energy Production

Biogas is a renewable resource, and when it is converted to electricity it is replacing power than would otherwise be produced from fossil fuel sources

(iii) Pathogen Reduction

Harmful pathogens are also reduced - although not eliminated - through digestion.

(iv) Greenhouse Gas Reduction
Methane produced is a contributor to global warming -methane is a powerful greenhouse gas 23 times more potent than carbon dioxide, the most common greenhouse gas. Capturing and burning this methane with an anaerobic digestion system reduces this greenhouse gas.

\section{Types of Bio-digesters}

A biogas digester is a structure designed to create anaerobic conditions for the decomposition to take place in and to safely store the resulting biogas produced in some way. The specific microbes (methanogens) that are responsible for the creation of biogas, can only do so in the absence of oxygen, hence the anaerobic conditions. The most well-known digesters around the world have either been the Fixed Dome Digester originating from China, or the Floating Dome Digester (also known as the Gobar Gas Digester) from India.

\subsection{Fixed Dome Digester}

As the name implies, this type of digester has a gas-collecting dome that is fixed. The digester is normally constructed using bricks and mortar and ends with a solid fixed dome in the shape of an igloo. Although this is the most well-known digester design and the most widely used, it has a number of inherent disadvantages.

The main disadvantage is the fact that it can only ever produce gas of variable pressure. As the biogas is generated it rises and accumulates in the brick dome from where it is piped to point of use. The volume and rate of gas production is dependent on the type and frequency of material fed into the digester as well as on the temperature. This means that the amount and pressure of gas available will continuously vary, making it less efficient to run any type of biogas equipment such as gas water heaters, lights and generators.

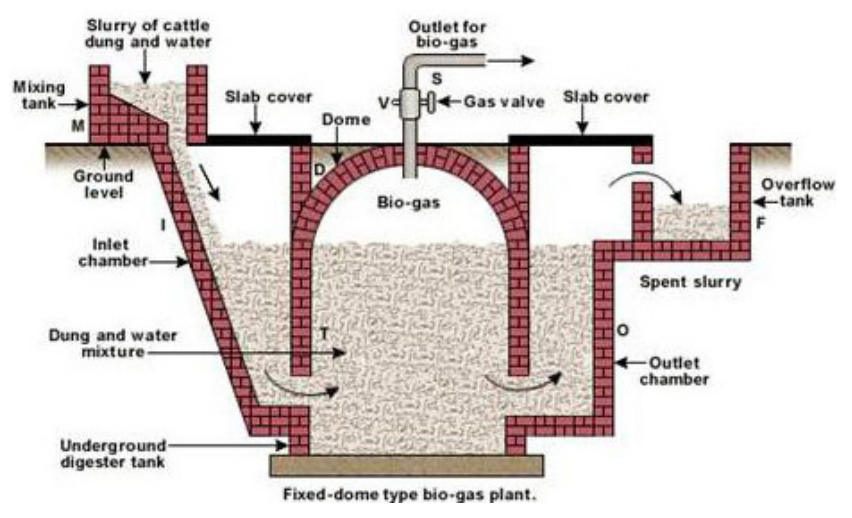

Figure 1. Fixed dome digester

The second disadvantage is related to the actual construction of the digester which requires a very high level of skilled labour. Constructing a dome using bricks and 
mortar is a task suitable only to a very experienced brick layer and is also time consuming. A critical aspect of a digester is that it has to be constructed and sealed in such a way that it is airtight - any crack in the structure will allow the biogas to escape. History has shown that this aspect has been the biggest cause of failure of fixed dome digesters due to the development of cracks as the cement cures and/or as a result of differential settlement of the structure. More than $50 \%$ of this type of digester has a functional life span of more than 3 years.

\section{Floating Dome Digester}

A floating dome digester is designed in such a way that it has a dome (normally made of steel) that fits in the neck of the digester and basically floats on the gas produced in the belly of the digester below. As gas is produced in the digester it collects in the dome, eventually creating enough pressure for the dome to in effect "float" on the gas.

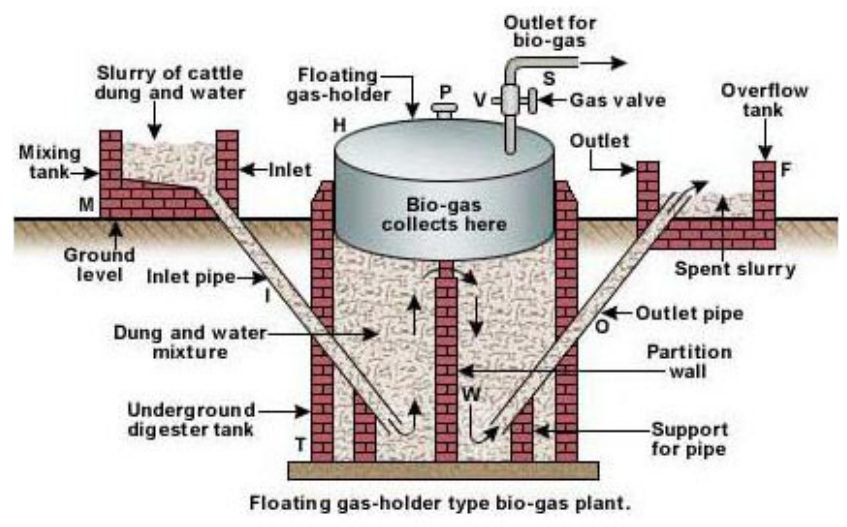

Figure 2. Floating dome digester

The floating drum normally has a central steel pipe which facilitates its vertical up and down movement and also has metal guides built into the sides of the digester. The weight of the floating steel cylinder ensures that the gas produced is under constant pressure, which gives this type of digester its main advantage. Unfortunately this advantage also results in this type of digesters main disadvantage as the sliding mechanism requires specialized design and construction, is costly and further requires constant maintenance. Similar to the fixed dome digester, a high level of skilled labour is also required to construct this type of digester, which in turn becomes time consuming.

\section{Study Area}

Umande trust is a civil society organization working closely with communities, public agencies and the private sector to improve access, for all, to safe, adequate and affordable water and bio-sanitation services. We are part of a growing number of agencies promoting the effective use and replication of a variety of hygiene, water and eco-sanitation options with people- principally in Nairobi, Kisumu, Nakuru, Embu and Homa Bay in Kenya.

The team has extensive experience in the design, planning and sustaining of bio-centres in Kenya principally in low-income urban settlements and schools (such as Mbaga Girls, Nyabondo Primary, Machakos Girls, Karima Girls and Kianyaga Boys amongst many others. Of particular emphasis, our team has expertise in engineering and technical designs with people, facilitating transparent and accountable construction governance, hygiene promotion and business development services to ensure that the completed facilities remain serviceable and bankable.

The largest of Nairobi's informal settlements is Kibera, just three miles from the city centre. An estimated one million people live there, and toilet facilities are scarce. The bare earth streets are carved with gullies: equal parts open sewer and rubbish dump. The nearest toilet for most people is a hole they have dug in a bare patch of ground at the back of their shack.

\section{Locations of Bio-centres in Kibera Informal Settlements}

Umande Trust and its partners have built 57 bio-centres in Nairobi - 21 being constructed in Kibera - which have so far managed to collect at least $60,000 \mathrm{~kg}$ of human waste [2]. The construction of these facilities in these densely populated settlements faced a number of challenges that include transportation of heavy building materials across dirt streets raven with gullies and piled high with detritus is not easy, and theft of building materials. To ensure successful implementation, Umande Trust held negotiations and the community helped to transport the building materials, and keep them secure while the facility was being built. 


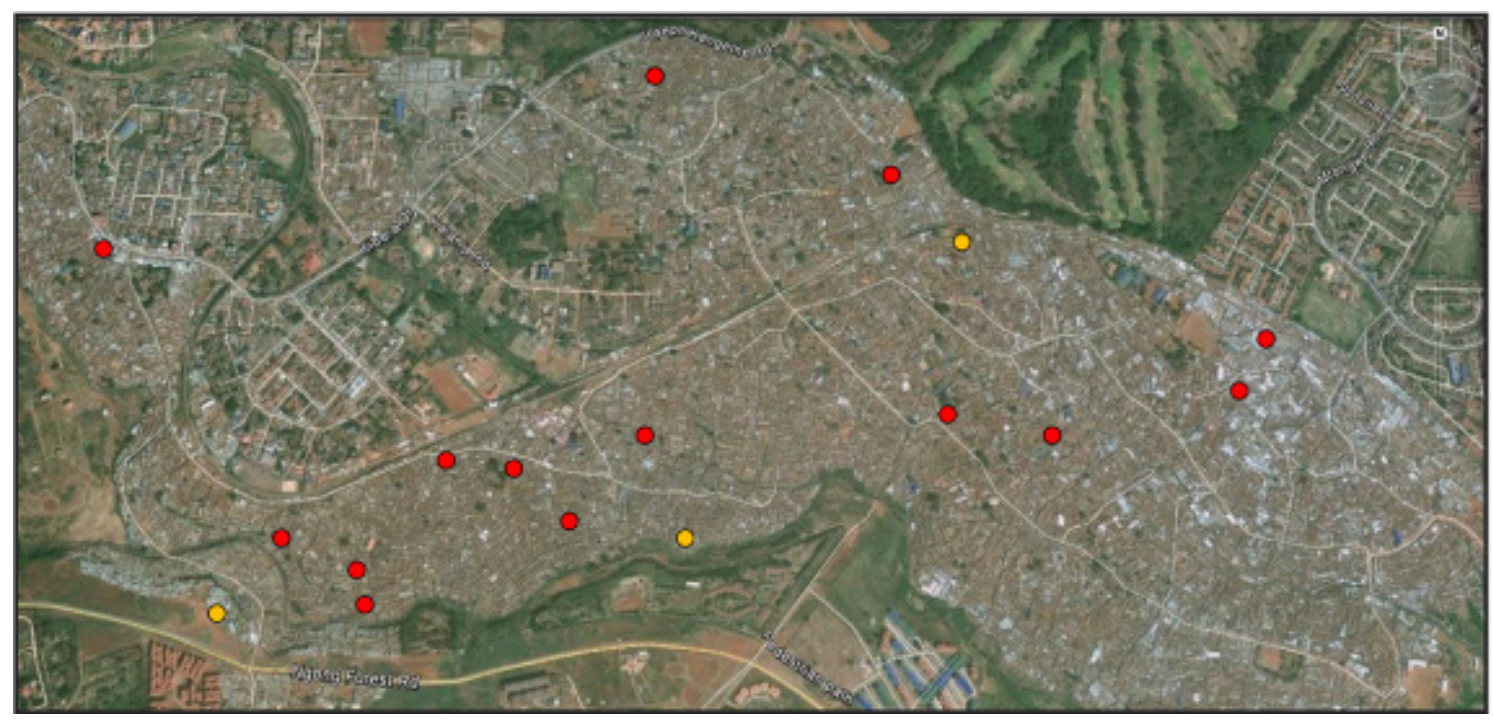

Map 1. Location of bio-centres in Kibera

\section{Three "Snapshot" Cases}

\section{(i) Lindi Usafi Bio-centre}

Tucked within a collection of housing structures in Lindi, the bio-centre was first initiated in 2006. Since its inception, this bio-centre has immensely improved the sanitation of the surrounding areas, a decrease in illness within the community, and acted as a new location for community members to hold events and activities.

Unique to this bio-centre is its connection to a nearby set of latrines. These latrines have a history of their own, once being dilapidated to the point of extreme disgust (Plate 1). Umande Trust, having already constructed the Lindi Usafi bio-centre, consulted with the community and agreed to help renovate the latrines and connect these latrines' waste to the bio-centre. As a result, the Lindi Usafi bio-centre is able to use the waste from these latrines to produce biogas. Without the partnership between the latrines and the Lindi Usafi bio-centre group, the renovation and sustainability of these community latrines would be much more difficult and possibly would not have happened.

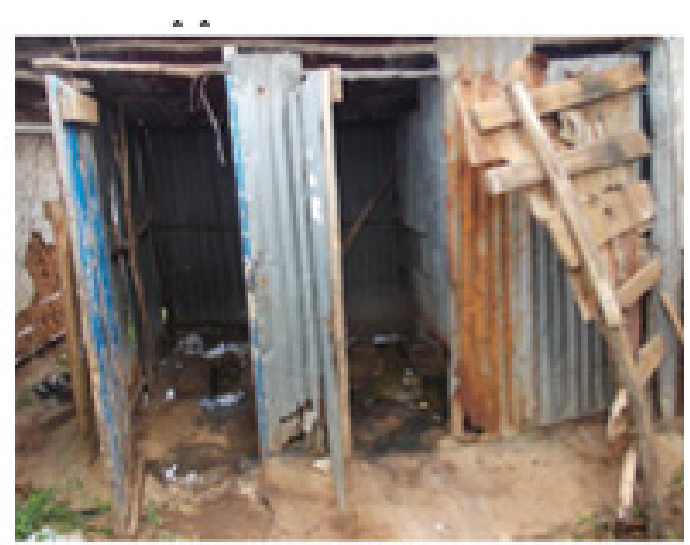

Before

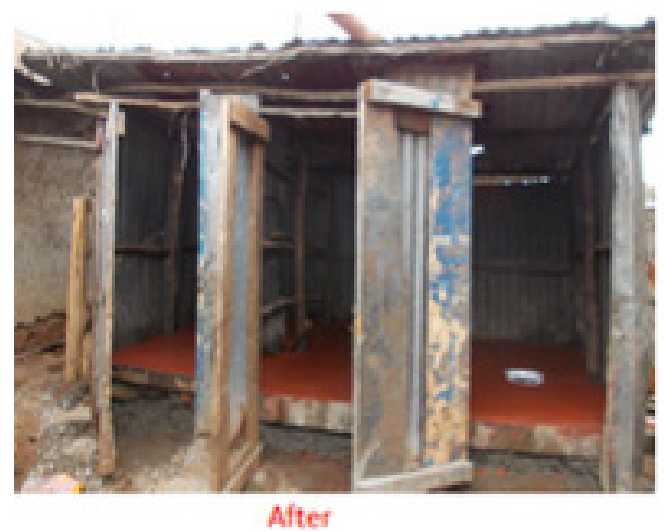

Plate 1: Latrines

The success of the bio-centre and latrines is sustained by 37 member groups, who have spearheaded the sustainability of the bio-centre. The bio-centre has a community room that is used to host events such as church group meetings, elderly group meetings, and football match viewings.

\section{(ii) Gatwikira Multi-vision Bio-centre}

The bio-centre became operational in 2008. It is able to serve between 250-300 people daily, including men, women, children, and the disabled. In addition, the bio-centre offers toilets, cold showers, hot showers, biogas for cooking, and a community centre on the upper floor of the building. Gatwikira has been able to put in place a cashless payment system, which has increased transparency and accountability for the group, and has increased security for the caretakers and the bio-centre's users, who do not need to carry cash in order to use the bio-centre. 


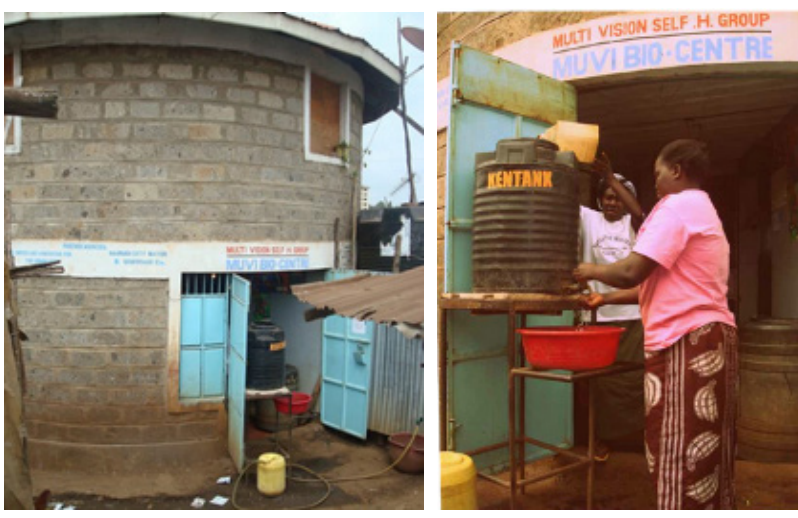

Plate 2. Water at bio-centres

\section{(iii) Jasho Letu Bio-Centre}

This bio-centre was created in 2007. Jasho Letu offers both daily and monthly payment for use of its toilets and cold showers. One time use of the toilet and shower cost Ksh. 5 (US\$ 0.05) and Ksh. 10 (US\$ 0.11) respectively, while monthly use costs Ksh.150 (US\$ 1.7). Overall, the centre is able to collect approximately Ksh. 7,000 (US\$ 77.78) a week.

One factor attributing to its success is the introduction of a cashless payment system that allows for both mobile payment and electronic transfer of cash transactions. The centre has partnered with Safaricom, Kenya's leading mobile telephone service provider, to effect payments through their platform. They have created an open-loop platform - called Kopo Kopo-which allows customers to pay for bio-centre services using Safaricom's M-PESA service to top-up credit on their mobile phone. With M-PESA, customers can immediately pay for bio-centre amenities and are not charged any additional fees. Jasho Letu is charged 1\% lumpsum each time the Kopo Kopo transactions are settled to their bank account.
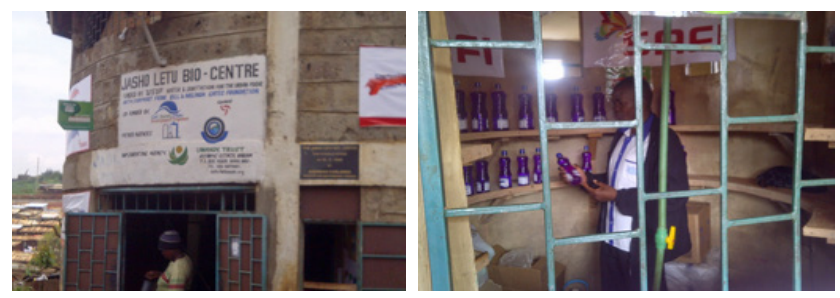

Plate 3. Activities at bio-centres

The Kopo Kopo system also allows caretakers to electronically submit, transfer, and record cash payments with the M-PESA mobile wallet platform. Through the Kopo Kopo payment methods - mobile and cash - there has been improved accountability and record-keeping for the bio-centre.

Another major success of the Jasho Letu bio-centre is the sale of cooking fuel. Jasho Letu currently sells ethanol for Ksh. 87(US\$ 1) per litre, offering a sustainable, inexpensive, and healthier alternative to charcoal.

Evidently both the Kopo Kopo cashless payment system and the sale of biogas have led Jasho Letu's bio-centre to offer more than just sanitation. Along with the cashless payment systems and biogas, Jasho Letu's 2nd floor community center provides space for community collaboration or entertainment. Community based organizations have a space for meeting, and football fans have a safe opportunity to watch sports.

\section{Impacts}

According to Umande Trust Project Director, Aidah Ebrahim, between 350 and 1,000 people visit each of the toilet blocks every day, paying three cents each to use the toilets, and a few cents more for a hot shower, if those are available. Bio-centres in Kibera have so far collected approximately $60,000 \mathrm{~kg}$ of human waste, turning it into biogas.

\section{(i) Products}

Many products and services are generated at the bio-centres. These include adequate toilets and showers and safe spaces for local organization meetings, community cooking, or entertainment like football game viewing. In addition, the bio-centers provide income generation for their operating community-based organizations through the provision of facility services and conversion of human waste into clean energy (biogas) and fertilizer for urban greening.

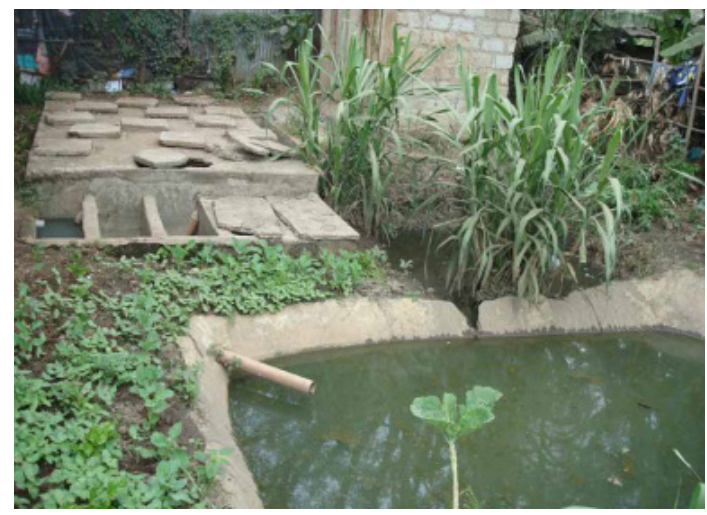

Figure 3. Water re-use in a fish pond

Umande Trust is currently in the planning stages of building a biogas and fertilizer plant in the informal settlement of Kibera in Nairobi. This plant will harness biogas from the human waste collected at Umande's bio-centres around Kibera, as well as vegetable waste from markets in Kibera. The plant will produce packaged biogas and liquid and solid fertilizer, and will be run by a community-owned business unit. This project will address a number of issues in the community: it will decrease emissions of greenhouse gases, increase incomes for vulnerable communities in urban informal settlements, increase the use of organic fertilizer in agriculture, and supply the Kenyan market with biogas as an alternative to petroleum based LPG. Umande hopes that this project will 
help close the urban - rural cycle of nutrients between human waste and the agricultural fields by returning the slurry that remains after gas production back to the fields as an excellent organic fertilizer.

\section{(ii) Payment Systems}

The bio-centre initiative has an intentional focus on experimenting with innovative payment systems, technology, and money management tools that cost-effectively contribute to facilitating innovative pricing structures and improve upon burdensome and inefficient cash management practices. The project intends to leverage electronic/mobile technology in order to facilitate the new pricing models and track performance in a more systematic way. This shifts payments away from small cash transactions that are difficult to track and cumbersome to get into the bank, and towards larger periodic transactions that are easily tracked and even automatically transferred into bank accounts. To this end, the project has a component called the Sanitation Payment Fund ("SanPay")to explore such payment system innovations.

\section{(iii) Pricing}

Pricing of services has been done to match household cash flow realities and decision-making dynamics, to encourage frequent use of the bio-centres. Instead of just pay-per-use for individual services, weekly or monthly pricing that provides unlimited access to all members of the household, along with offering "bundles" that combine the price of toilet access with other basic household services, such as water, bath, cooking fuel, or housing have been introduced.

\section{(iv) Open Defecation Free Zones}

Umande Trust has initiated an open defecation free (ODF) zone assessment for bio-centre catchment areas. This initiative helps to assess how effective communities living 60-100metre radius of the bio-centres are utilizing the centres and hence not throwing "flying toilets". The goal of this initiative is to see the achievement of the universal usage of toilets.

\section{Conclusions}

The bio-centres have had marked positive impacts in Kibera. They have improved the health of the community. They have also immensely improved the surrounding environment by ridding it of the "flying toilet". The centres have further enhanced community cohesiveness and improved the livelihoods of Kibera residents. As a principle, sanitation by-products are being optimized as resources and not discarded as waste in this informal settlement. This sanitation value chain project is profitable and scalable.

US $\$ 1=$ Ksh. 90

\section{REFERENCES}

[1] Umande (2014). Endangering positive change in slums. Umande Trust, Nairobi

[2] Omotto (2014). Personal conversation with chief executive. Umande Trust. Nairobi

[3] Clean energy resource teams manual. Biogas digesters. Retrieved on 07.04.2015 from http://www.cleanenergyresour ceteams.org/files/CERTsManualCh7.pdf

[4] Seadi,T, Rutz,D, Prassl,H, Köttner,M, Finsterwalder,T Volk,S, Janssen, R. (2008). Biogas Handbook. University of Southern Denmark

[5] What is a digester? Retrieved on 07.04.2015 from http://www.biogassa.co.za/digesters.htm 